This item was submitted to Loughborough's Research Repository by the author.

Items in Figshare are protected by copyright, with all rights reserved, unless otherwise indicated.

\title{
The role of familial habitus in shaping children's views of their future employment
}

PLEASE CITE THE PUBLISHED VERSION

http://dx.doi.org/10.1080/14733285.2011.540443

PUBLISHER

(C) Taylor \& Francis (Routledge)

VERSION

AM (Accepted Manuscript)

LICENCE

CC BY-NC-ND 4.0

REPOSITORY RECORD

Pimlott-Wilson, Helena. 2019. "The Role of Familial Habitus in Shaping Children's Views of Their Future Employment”. figshare. https://hdl.handle.net/2134/9749. 
This item was submitted to Loughborough's Institutional Repository (https://dspace.lboro.ac.uk/) by the author and is made available under the following Creative Commons Licence conditions.

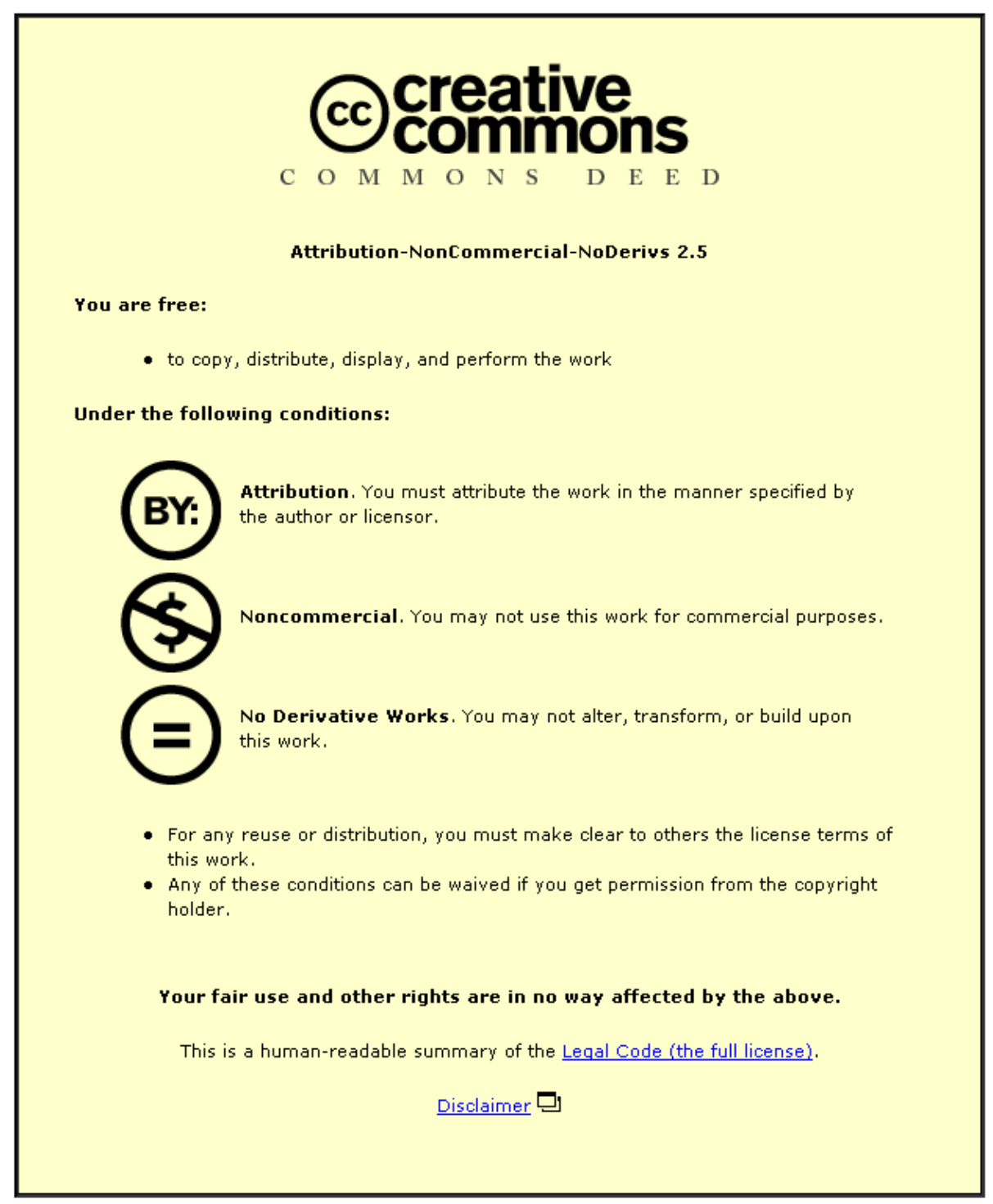

For the full text of this licence, please go to: http://creativecommons.org/licenses/by-nc-nd/2.5/ 


\section{The Role of Familial Habitus in Shaping Children's Views of their Future Employment}

\section{Helena Pimlott-Wilson}

Department of Geography, Loughborough University, Loughborough, Leicestershire, LE11 3TU, UK h.pimlott-wilson@lboro.ac.uk

Keywords: Geography; Children; Employment; Aspiration; Parenting; Socialisation;

\section{Introduction}

As the field of Geographies of Children, Youth and Families grows and diversifies as a testament to the active and vigorous interest in this area of research, the collection of papers presented within this Special Issue proves timely in addressing developing research on education and aspiration. At a variety of spatial scales and from different perspectives, the contributors have shown how educational settings are invoked by politicians, educators and practitioners as sites where the aspirations of future citizen-workers can be managed for perceived individual and collective benefit. It is unsurprising that young people remain the focus of policy attention and analyses in relation to 'raising' aspirations, given normative understandings of their chronological proximity to transitions to adulthood. What emerges alongside efforts to affect the aspirations of young people through education is a strand of thought which acknowledges the role of the family in the lives of young people. Research has shown distinctions in parental aspirations for their children according to ethnic and socio-economic background (Coleman, 1988; Portes and MacLeod, 1996), and has highlighted how families are viewed by educationalists as key to the academic success of their children (Holloway and Pimlott-Wilson, this issue). Whilst young people and parents remain central to considerations of aspiration (Nairn et al., 2007), the hopes of young children are also crucial when we take into account the implications which may arise when children judge one path of action feasible as a future goal whilst others appear unattainable. 
In this article, I argue that the voices of children need to be included in research which considers aspiration, acknowledging the influence of the family on these imagined futures whilst also recognising that children reflexively develop their own perspectives as they encounter new experiences. In the next section of the paper, I engage with policy interest in families and discuss further my conceptualisation of habitus and how this relates to children's hopes for the future. In the central section I present a case study of children's future employment plans, putting forward evidence to show that family socialisation predisposes children to consider particular occupational types over others. To this end, I utilise the concept of habitus as a flexible and non-deterministic method for understanding children's perceptions of what courses of action are most appropriate for their future. Thirdly, I provide evidence to suggest that children's aspirations are not simply a reflection of parental practices but rather show how the habitus is continually evolving, illustrating children's agency in their reflexive resistance of particular occupational types in light of family experience. In conclusion, the article calls for further consideration of children's hopes for the future and the factors which influence the dispositions of individuals, highlighting the imperative for educationalists to remain cognisant of children's dispositions in efforts to (re)shape aspirations.

\section{Policy context}

Citizen-state relations in England have undergone change in the past decade, with emphasis placed on the responsibilities of individual citizens to provide for their own needs rather than state welfare (Raco, 2009). Workfare-orientated economic policies expect citizens to engage in employment and life-long learning, and take social responsibility in order to achieve a cohesive and inclusive society. Whilst the social agenda focuses on inclusion and individual responsibility, families are positioned as the building blocks of the elusive stable and cohesive society. Responsibility for social reproduction has undergone change, as families are expected to provide for their own welfare needs, yet Governments express concern over the future potential of children (Jenson, 2004), as childhood has become a 'site of accumulation' for both families and the state (Katz, 2008). Policy interpretations of idealised parenthood have come to encapsulate "middle-class resources, dispositions 
and values” (Reay, 2008: 643) whilst those who deviate from this standard are positioned as socially excluded, detached from mainstream morals and norms. The Labour Governments' 'welfare to work' agenda highlights the importance of childcare to enable mothers to (re)enter the labour market (Osgood, 2005) yet policy overlooks the type of labour market work which mothers do and the effect this has on their children.

Whilst government policy encourages parental employment, young people also become the focus of state intervention. Education is one such political tool through which future citizen-workers can be produced and their aspirations moulded. Aspirations are complex understandings of the future pathways available to people, influenced by individual experiences and those of the family, which emerge within particular social, economic and cultural circumstances (Ball et al., 2002). In her study, Crompton (2000) identifies sectoral differences in the values, aspirations and expectations of different (adult) middle class groups towards work-life reconciliation, contributing to the intergenerational transmission of occupational types and affecting social mobility. Political reference to the concept of aspiration is often made in deficit terms, as pupils from low socio-economic status backgrounds are framed as lacking appropriate (middle-class) aspirations, which educational institutions must work to 'raise' (Brown, this issue; Holloway and Pimlott-Wilson, this issue). This disparaging of alternative value systems within policy draws attention away from the economic context in which families raise children, viewing families as a significant domain through which economic and political stability and order can be achieved (Edwards, 2004). The socialisation of children within the family is therefore a key issue when thinking about aspirations, given the role assigned to parents and their prominence in policy interventions.

\section{Family socialisation and habitus}

In a climate where parents are increasingly accountable for their children's outcomes (Holloway, 1998; Reay, 2005), diverse patterns of family socialisation provide scope for geographical study investigating the implications for wider society (Bondi and Matthews, 1988). Despite literature which suggests that individuals are the authors of their own biographies and have more choices (Beck, 1992; Beck and Beck-Gernsheim, 2002), the family continues to play a key role in the reproduction of 
social class and class inequalities (Crompton, 2006), with class differences in the way children are socialised (Lareau, 2003). Representing a collection of durable, transposable dispositions which generate and organise practices, habitus is unconsciously developed from a young age through family practices (Dumais, 2002). It places weight on past experience through the unconscious socialisation of different social groups, to make individuals aspire to possibilities that they think are feasible and seem within reach (Bourdieu, 1990).

The habitus is not a form of determinism; it simultaneously predisposes people towards certain ways of behaving whilst enabling individuals to draw on alternative courses of action (Reay, 2004). As the product of early childhood experience, in particular socialisation in the family, habitus is continually discovering alternative pathways through encounters with the outside world. Habitus can be replicated by exposure to conditions which reproduce dispositions, or transformed though process to raise or lower individual's aspirations (Reay, 2004). As Bourdieu suggests,

"The habitus acquired in the family is at the basis of the structuring of school experiences; the habitus transformed by the action of the school, itself diversified, is in turn at the basis of all subsequent experiences, from restructuring to restructuring” (Bourdieu 1972, cited in Reay, 2004: 434).

Consideration therefore needs to be given to how children perceive and make sense of the habitus, acknowledging their active role in the creation of their own life paths and the simultaneous influence of social conditions. The habitus is not fixed, and is responsive to the ongoing dialogue individuals have with their self and others (Holdsworth and Morgan, 2007).

As part of a broader study investigating children's opinions of parental employment, this article draws on the voices of 124 individuals in Year 1 (aged 5-6) and Year 4 (aged 8-9) from a wide range of social class backgrounds in Cumbria, England. Although Cumbria is often associated with the Lake District, parts of the county experience high levels of poverty and deprivation similar to other urban and former industrial centres in the northwest region (Cumbria County Council, 2009). Cumbria's labour force therefore shares significant features with the national picture of employment, including female labour force participation. The research engages 
with the hopes ${ }^{1}$ children have for the future in terms of the occupational position they would like to achieve. It will address the lacuna in the literature by presenting empirical evidence of how children form visions of their future in relation to family socialisation. I will then demonstrate that children's aspirations are not simply a reflection of familial practices but that the habitus is informed by wider processes.

\section{A case study of parental employment: Agreement and conformity}

In quantitative and qualitative research, theories of intergenerational occupational inheritance are utilised to account for low absolute social mobility in the UK, drawing on outcomes for adults (Blanden et al., 2010; Devine, 2004). By listening to the voices of children, it is possible to reveal how they position particular occupations as a rational choice, based on family practices:

HPW: Is there anything that you'd like to be?

Ray: At the moment, my line is being a solicitor because my mum and dad are (Year 4, EM $\left.{ }^{2}, \mathrm{EF}\right)$.

Sophie: I would best [go] to work down town and get work...

HPW: What would you like to be, what type of job?

Sophie: A shop

HPW: In a shop?...

Sophie: 'Coz my dad works in shop (Year 1, EM, EF).

Chesney: I want to be a few things but most of all I would like to be a vet like my mum and dad (Year 4, EM, EF).

TJ: [I would like to be] a big man builder

\footnotetext{
${ }^{1}$ In this paper, I use the terms 'hopes' and ‘aspiration' interchangeably in relation to children's views of their future occupational position. Their responses were ascertained by asking (if they expressed a desire to work), the type of job they would 'like to do' in the future. I believe these are distinct to the job they 'expect' or 'plan' to do (Nilsen, 1999; see Brown (this issue) for a fuller distinction between 'aspiration' and 'expectation').

2 'EM' denotes a child with an employed mother; 'NEM' a non-employed mother. 'EF' indicates an employed father/ father-figure, 'NEF' a non-employed father/ father-figure. Where the employment status of a parent is not indicated, the child did not identify that parent to be involved in their life.
} 
HPW: You'd be a builder? Right and why do you want to be that?

TJ: Like my grandad (Year 1, NEM).

These children all express a desire to follow in the footsteps of family members in one way or another, trammelling the same furrows as they grow up (Baker and Brown, 2008). Children believe that by replicating well-trodden family paths, particular job types will be available to them. For Ray and Chesney, socialisation within the family is bound up with the habitus, directing them towards professional employment whilst the same process acts to make routine and craft work more appealing to Sophie and TJ. In their study of Higher Education (HE) choices, Ball et al. (2002) show how the narratives of middle-class young people are characterised by an absence of decisions and reflect family traditions, contrasted with the doubts and deliberate decisionmaking of working-class young people who are the first generation of their family to consider HE. As a result, the (non)decision to follow a professional career path is easier for some individuals. Whilst avoiding a deterministic interpretation of the imagined futures of Ray, Sophie, Chesney and TJ, it is clear that particular courses of action seem more 'common-sense' to these children, and how this process is inculcated in the habitus through the repeated actions of their family. In the context of low social mobility in the UK, this decision-making by children gives an insight into how particular job types are inculcated to produce a set of occupations which seem reasonable for different children to aspire towards. The choices which families make in relation to employment, within the constraints of local economic conditions, are thus significant for children as they imagine their future.

Within the sample, some children expressed a desire to replicate longestablished patterns of gender- and occupational- based employability within their family, drawing on the concept of an intergenerational chain which they did not wish to break. The pattern of employment followed by a woman's mother has been shown to be one of the key factors in influencing women's own decisions to work (Jenkins, 2002) and is found in the accounts of Gemma and Wayne:

HPW: Do you think it makes any difference that she [grandma] used to work, and then your mam works and then you want to work?

Gemma: Yeah, its like, ‘coz, my mam’s mam she worked, my nan’s mam’s mam she worked, so like all the ladies worked in the family and my mam's 
working and if I work and my children work, like my babies, my girls, if they work, they can like pass it on and they can see how long the tree ends at (Year 4, EM, EF).

Wayne: [I'd like to] work at [a quarry] like my dad coz, his granddad used to work there and he was a driver...And my nana and auntie, and all my uncles and aunties works there, at [the quarry] (Year 4, EM, EF).

Children express their anticipated future to be predictable, rooted in the wellestablished lifeworlds of their family, following a 'normal biography' which in some cases, follows gendered traditions (Ball et al., 2002; Du Bois-Reymond, 1998). The type of employment characteristic of this chain was also important to children. Olivia tempered her own aspirations for a career in professional sport with an expectation that a career in the police service may be a more realistic and family-sanctioned choice:

sometimes 'coz if all my family ... are saying 'just keep the chain going, keep the chain going' like that so if I don't get to be what I want to be [professional swimmer] I will go, I'll think about being a police officer [like my mum] (Year 4, EM, EF).

The views of family members are therefore important to children as they come to formulate their own ideas about their future; in Olivia's case, creating a distinction between aspiration and expectation. While considering employment, children also consider the likelihood of achieving their desired future outcomes and the acceptability of their choices within familial structures.

Research which considers the effect of family background on the labour market choices and outcomes of young people highlights the importance of class and social context (Forrest and Kearns, 2001; Green, 1997). MacDonald et al. (2005) suggest that long-term experiences of 'poor work' in families and social networks influence the transitions of socially excluded young adults as class and place provide limited opportunities for escaping conditions of social exclusion. In the children's accounts presented here, it is also clear that they are predisposed towards particular jobs and the local labour market in which they are located through the practices of 
their family. Choosing not to engage in the labour market is a choice voiced by children who have family experience of non-employed parents:

Tracey: He [step-dad] used to have one [a job] but he hasn't now...'Coz my mam doesn't want him to have the job.

HPW: Why does she not want him to have a job?

Tracey: ‘Coz she, my mam hasn’t got a job....

HPW: Would you work?

Tracey: (shakes head)

HPW: No, you wouldn't want a job, why not?

Tracey: ‘Coz my mam hasn’t (Year 1, NEM, NEF).

Tracey's preference for not being employed when she is older resonates with research which looks at the intergenerational transmission of unemployment (Machin, 1999), showing that such decisions can be made at a relatively young age. Familial habitus can result in a tendency for young people to replicate (non)employment patterns that are acceptable within their family, such as in relation to HE (Reay, 1998). Disadvantaged families, such as Tracey's, may therefore need more reassurance of the benefits of more costly courses of action which are beyond their own immediate experience (Devine, 2004). Kye explicitly discusses how familial patterns of (un)employment predispose children to aspire towards particular future paths over others, mirroring the concept of an intergenerational chain which other children discussed:

they'd [children with non-employed parents] be more like their dads, mam and dads because... they want to go through the same, as if they never got a job, like their mam's and dads' did, ...so they'd follow on (Kye, Year 4, EM, EF).

However, through dialogue with other children, I would argue that the dispositions which are incorporated into the habitus are not a simple reflection of familial practices, and that children actively calculate the costs and benefits of particular courses of action, based in the experiences of family members but also other influences as they grow up. In the next section, I present empirical evidence that suggests children negotiate divergent influences in their formation of aspirations. 


\section{Showing challenge}

Whilst children inculcate family practices into the habitus, their aspirations for their own future are not simply a carbon copy of what has occurred before. Social circumstances and schools can act to replicate or transform dispositions (Reay, 2004), changing the way children come to view their future employment possibilities. Violet draws on both familial and educational experience in her own future aspirations, suggesting she would like to be "either a teacher, a hairdresser or a bar maid [mum's job]... ‘Coz my auntie Lou's a hairdresser” (Year 4, EM, EF). Violet's discussion illustrates that children's aspirations are influenced by more than just the family, as she also suggests that she would like to be a teacher. Children in the UK spend sustained periods of time at school, and Violet's aspirations demonstrate how she has been affected by the individuals with whom she has been in contact. This highlights the importance of exposing children to employment possibilities which are different to those which they might normally encounter in their families; yet this contact ought to be sustained in order to have lasting effects. Children can thus acquire aspirations from other spheres which may not be part of the socialisation they have received in the family. This therefore suggests that alternative pathways can be open to them, should they encounter a trajectory which appeals to them. Holly stated that she would like to be different to her own mum and be employed "because I wouldn't have as much debts as her" (Year 4, NEM). I suggest that children can learn from the negative experiences of family members and therefore that the habitus is adaptive. In making a conscious decision not to replicate the perceived mistakes of their family in their life-worlds (should they come to view their actions in such a way), the dispositions of individuals alter. Children cannot therefore be presented as simply the passive recipients of socialisation in all circumstances with a limited repertoire of social responses (Edwards, 2004; Holdsworth and Morgan, 2007; Reay, 2004). Chloe recognised the boredom and lack of financial resources that come from prolonged spells of time at home, expressing a desire to break away from the example of her mother:

Chloe: [I would like to work] because you'll get money and you don't have to like, you don’t have to stay at home all day and wonder what to do all day. 
HPW: Ok, do you think your mum wonders what to do? Does she ever talk about that?

Chloe:... Sometimes she, in the mornings, she takes us to school and she comes back and sleeps until about 12 o'clock (Year 4, NEM, EF).

Emily: She's [mum] in the police... She goes at, different times, sometimes she's there really early in the morning or she comes back early in the morning about 4 o'clock or 2 o'clock... [I do not want that job] 'Coz you have to wake up really early in the morning (Year 1, EM, EF).

Edward: because they've [mum and dad] both got different jobs, and so I thought that I should have a different job too (Year 4, EM, EF).

These children are expressing what Du Bois-Reymond (1998) would term 'choice biographies', reflecting on the choices available to them and justifying their decisions. Children are making deliberate decisions which do not always follow intergenerational patterns of (non)employment, and some can see alternative pathways to those offered by family example. This suggests that the family influences children's habitus by predisposing them to particular courses of action, whilst also showing some children by example that particular courses of action are less desirable.

\section{Conclusion}

In this article, I utilise habitus not as resulting in inevitable outcomes for children, but as a way of understanding the courses of action which individuals deem (un)attainable in their future. Children are expressing their imagined futures, based on 'family scripts' (Ball et al., 2002) which comprise economic, social and cultural resources developed within the family. However, this is not to say that what children believe is (im)possible currently will always be so, but to demonstrate that the influence of the family should not be lost in wider analyses of social, economic and political processes acting at the macro level. Habitus is therefore not totally restrictive, allowing individuals to encounter new experiences and alter their path, as well as trammelling them into familiar ones. 
As geographers of education recognise the role of the family in affecting decisions relating to education (such as school/ university choice), it is important to be mindful of the influence of the habitus formed in the family in structuring school experiences (Bourdieu, 1992, cited in Reay, 2004). In relation to HE choice, Ball et al. (2002) suggest a relationship between family and institutional habitus, as embedded expectations make particular choices obvious and others unthinkable. However, in the accounts of the children presented here in relation to their employment aspirations, there is little consideration of the institutional habitus, as the family is the starting point from which the children in this sample make their decisions. Whilst influences within educational settings cannot be ignored, the deeply embedded dispositions formed within children's family backgrounds remain significant, at least for the age groups presented here, in making certain future pathways desirable.

Within education settings, certain values and dispositions, acquired through processes of socialisation, continue to be endowed with greater value (Ball et al., 2002; Holloway and Pimlott-Wilson, this issue). Those who possess the appropriate values and dispositions are more able to navigate their way through the field of education, reproducing advantage (Bourdieu, 1984). Furthermore, research has shown that the occupational position of parents has an affect on the intergenerational transmission of occupational types and social mobility for adults (Crompton, 2000). By reflecting on the aspirations of a sample of children, this article has shown that children's dispositions clearly replicate the conditions surrounding them, including societal norms (Brannen and Nilsen, 2007), and although they are some distance between their immediate realities and future decisions, their imagining of the future is nonetheless significant. The paper has also indicated that educational settings can have a degree of effect on children's aspirations. Whilst it may be more desirable to 'raise' aspirations - from an economic and political perspective to create citizenworkers for the future, and ethically in terms of strengthening people's socioeconomic position - educationalists need to be cognisant of children's dispositions, providing appropriate resources to develop future pathways which appear realistic whilst also tackling low social mobility.

\section{Acknowledgments}


I would like to thank the ESRC for funding the research upon which this article is based. Many thanks also to Sarah Holloway, Johanna Waters, Gavin Brown and Tracey Skelton for their comments on an earlier draft of this paper and to the children who took part in this research.

\section{References}

Baker, S. and Brown, B. 2008. Habitus and homeland: educational aspirations, family life and culture in autobiographical narratives of educational experience in rural Wales. Sociologica Ruralis, 28(1): 57-72

Ball, S.J., Davies, J., David, M. \& Reay, D. 2002. 'Classification’ and 'judgement': social class and the 'cognitive structures' of choice of higher education, British Journal of Sociology of Education, 23(1): 51-72

Beck, U. 1992. Risk society: towards a new modernity. Sage, London Beck, U. and Beck-Gernsheim, E. 2002. Individualization. Sage, London Bondi, L. and Matthews, H. 1988. (Eds.) Education and society: studies in the politics, sociology and geography of education. Routledge, London Brannen, J. and Nilsen, A. 2007. Young people, time horizons and planning: a response to Anderson et al. Sociology, 41(1):153-160

Bourdieu, P. 1984. Distinction: a social critique of the judgement of taste. Harvard University Press, Cambridge, Massachusetts

Bourdieu, P. 1990. The logic of practice. Cambridge, Polity Press

Coleman, J.S. 1988. Social capital in the creation of human capital. American Journal of Sociology, 94: 95-120

Crompton, R. 2000. The gendered restructuring of the middle classes. In Crompton, R., Devine, F., Savage M. and Scott, J. (Eds) Renewing Class Analysis.

Blackwell/The Sociological Review, Oxford

Crompton, R. 2006. Class and family. Sociological Review, 54(4): 658-677

Cumbria County Council 2009. Anti-poverty strategy. Carlisle, Cumbria County Council

Devine, F. 2004. Class practices: how parents help their children get good jobs.

Cambridge University Press, Cambridge

Du Bois-Reymond, M. 1998. 'I don’t want to commit myself yet': young people’s life concepts, Journal of Youth Studies, 1(1): 63-79 
Dumais, S.A. 2002. Cultural capital, gender, and school success: the role of habitus, Sociology of Education, 75(1):44-68

Edwards, R. 2004. Present and absent in troubling ways: families and social capital debates. The Sociological Review, 52(1): 1-21

Forrest, R. and Kearns, A. 2001. Social cohesion, social capital and the neighbourhood. Urban Studies, 38(12): 2125-2143.

Green, A.E. 1997. Exclusion, unemployment and non-employment. Regional Studies, 31(5): 505-520

Holdsworth, C. and Morgan, D. 2007. Revisiting the generalized other: an exploration. Sociology, 41(3): 401-417

Holloway, S.L. 1998. Local childcare cultures: moral geographies of mothering and the social organisation of pre-school education. Gender, Culture and Place, 5(1): 2953

Jenkins, S.P. 2002. To work or not to work? The complexity of women's decision making. Gender Research Forum, November 2002 Jenson, J. 2004. Changing the paradigm. Family responsibility or investing in children. Canadian Journal of Sociology, 29(2): 169-192

Katz, C. 2008. Childhood as spectacle: relays of anxiety and the reconfiguration of the child. Cultural Geographies, 15(1): 5-17

Lareau, A. 2003. Unequal childhoods: class, race and family life. University of California Press, California

MacDonald, R., Shildrick, T., Webster, C. and Simpson, D. 2005. Growing up in poor neighbourhoods: the significance of class and place in the extended transitions of 'socially excluded' young adults. Sociology, 39(5): 873-891

Machin, S.J. 1999. Childhood disadvantage and intergenerational transmissions of economic status. In: Persistent Poverty and Lifetime Inequality: The Evidence: Proceedings from a workshop held at HM Treasury. CASE report (5). ,CASE, LSE / HM Treasury, London, pp. 17-21

Nairn, K., Higgins, J. and Ormond, A. 2007. Post-school horizons: New Zealand's neo-liberal generation in transition. International Studies in Sociology of Education, 17(4): 349-366

Nilsen, A. 1999. Where is the future? Time and space as categories in analyses of young people’s image of the future. Innovation, 12(2): 175-194 
Osgood, J. 2005. Who cares? The classed nature of childcare. Gender and Education, 17(3): 289-303

Portes, A. and MacLeod, D. 1996. Educational progress of children of immigrants: the roles of class, ethnicity, and school context. Sociology of Education, 69: 255-275 Raco, M. 2009. From expectations to aspirations: state modernisation, urban policy, and the existential politics of welfare in the UK. Political Geography 28(7): 436-444 Reay, D. 1998. 'Always knowing’ and 'never being sure’: familial and institutional habituses and higher education choice. Journal of Education Policy, 13(4): 519-529 Reay, D. 2004. 'It's all becoming a habitus': beyond the habitual use of habitus in educational research. British Journal of Sociology of Education, 25(4): 431-444 Reay, D. 2005. Doing the dirty work of social class? Mothers' work in support of their children's schooling. Sociological Review, 53(2): 104-115 Reay, D. 2008. Tony Blair, the promotion of the 'active' educational citizen, and middle-class hegemony. Oxford Review of Education, 34(6): 639-650 